\title{
Pengaruh Lingkungan Kerja Dan Budaya Organisasi Terhadap Produktivitas Karyawan Pada PT. L'ESSENTIAL
}

\author{
Lucia Maduningtias \\ Dosen Fakultas Ekonomi Universitas Pamulang \\ Email : madulucia07@gmail.com
}

\begin{abstract}
ABSTRAK
Organisasi yang ada maupun yang di terapkan dan untuk mengetahui Produktivitas Karyawan PT. l'essential.

Metode penelitian yang digunakan adalah penelitian deskriptif/kuantitaf, yang artinya penelitian ini hanya sebatas pengungkapan suatu permasalahan yang ada dan mencoba menemukan solusi atau pemecahan masalah yang ada. Data yang diperoleh oleh kuesioner dengan jumlah responden sebanyak 50 orang. Dianalisis menggunakan bantuan Program microsoft Excel 2012 dan program SPSS 22 untuk melakukan Uji Validitas, Reabilitas, Normalitas, Parsial (t), Simultan (f) dan koefisien determinasi .

Hasil uji regresi linier sederhana menunjukan lingkungan kerja berpengaruh positif dan signifikan terhadap produktivitas karyawan dengan koefisiensi sebesar 0,694 dan nilai koefisiensi determinasi serta diperoleh persamaan regresi $\mathrm{Y}=$ $18,619+0,702 \mathrm{X}_{1}$. Hasil uji regresi linier sederhana menunjukan budaya organisasi berpengaruh positif dan signifikan terhadap produktivitas karyawan dengan koefisiensi sebesar 0,533 dan nilai koefisiensi determinasi serta diperoleh persamaan regresi $\mathrm{Y}=18,619+0,494 \mathrm{X}_{2}$. Lingkungan Kerja dan Budaya Organisasi secara bersama-sama berpengaruh positif dan signifikan terhadap Produktivitas Karyawan dengan persamaan $\mathrm{Y}=18,619+0,702 \mathrm{X}_{1}+0,494 \mathrm{X}_{2}+\mathrm{e}$ . Hasil ini juga ditujukan dengan nilai uji simultan (f) sebesar 47,810 dan koefisiensi determinasi 655. Hal ini menunjukakan variabel Lingkungan Kerja dan Budaya Organisasi secara bersama-sama memberikan kontribusi sebesar 65,5 $\%$ dan sisanya $34,5 \%$ dipengaruhi variabel luar penelitian ini. Dapat disimpulkan bahwa Ho ditolak $\mathrm{H} 1$ diterima, artinya ada pengaruh Lingkungan Kerja $\mathrm{X}_{1}$ dan Budaya Organisasi $\mathrm{X}_{2}$ secara bersama-sama terhadap Produktivitas Karyawan $\mathrm{Y}$ PT.l'essential.
\end{abstract}

Kata kunci: Lingkungan Kerja, Budaya Organisasi, Produktivitas Karyawan 


\section{PENDAHULUAN}

\section{Latar Belakang}

Berdasarkan penelitian yang saya amati pada PT. L'essential terjadi penurunan produktivitas karyawan khususnya dibagian produksi karena banyak faktor yang mempengaruhi lambatnya kinerja karyawan khususnya dibidang produksi yaitu kurangnya kualitas kerja, kuantitas kerja dan kecepatan kerja karyawan sehingga mempengaruhi hasil produksi yang diperoleh.

Lingkungan kerja yang baik memiliki peranan penting dalam meningkatkan produktivitas kerja karyawan dalam perusahaan. Karena lingkungan kerja merupakan salah satu hal yang dapat memotivasi karyawan untuk bekerja sangat baik. Lingkungan kerja yang baik dapat dilihat dari suasana kerja (yang meliputi: penerangan yang cukup, sirkulasi udara yang baik, tersedianya alatalat pengamanan, suara bising yang ditekan seminimal mungkin), dari kondisi hubungan karyawan serta tersedianya fasilitas pendukung lain. Dengan adanya fasilitas - fasilitas yang diberikan perusahaan, maka hal ini sangat berpengaruh langsung terhadap semangat kerja karyawan sehingga produktivitas pun meningkat. Ini adalah salah satu permasalahan yang sering di hadapi perusahaan yaitu bagaimana meningkatkan dan menjaga lingkungan kerja yang baik.

Menurut (Nitisemito dalam Nuraini 2013:97) lingkungan kerja adalah segala sesuatu yang ada disekitar karyawan dan dapat mempengaruhi dalam menjalankan tugas yang dibebankan kepadanya misalnya dengan adanya air conditioner (AC), penerangan yang memadai dan sebagainya. Oleh karena itu, produktivitas sumber daya manusia merupakan hal yang sangat penting di dalam usaha memperbaiki pelayanan kepada masyarakat, sehingga perlu diupayakan secara terus menerus dan berkesinambungan dalam menghadapi tuntutan masyarakat.

Budaya organisasi merupakan suatu ciri khas dari suatu perusahaan yang mencakup sekumpulan nilai-nilai kepercayaan yang membantu karyawan untuk mengetahui tindakan apa yang boleh dilakukan atau tidak dilakukan yang berhubungan dengan struktur formal dan informal dalam lingkungan perusahaan

Di L'essential pemberi motivasi ke karyawan masih belum optimal, ini terlihat dari tidak adanya penghargaan bagi karyawan yang berprestasi dan pengakuan dari perusahan, sehingga membuat kayawan malas dalam bekerja.

Dari indikasi tersebut maka penulis terinspirasi untuk melakukan penelitian tentang "Pengaruh Lingkungan Kerja Dan Budaya Organisasi Terhadap Produktivitas Karyawan Bagian Produksi Pada PT. L'ESSENTIAL'.

\section{Perumusan Masalah}

Dari identifikasi yang telah penulis kemukakan, maka penulis 
akan merumuskan permasalahan sebagai berikut :

a. Bagaimana pengaruh lingkungan kerja terhadap produktivitas karyawan bagian produksi Pada PT. L'essential?

b. Bagaimana pengaruh Budaya organisasi terhadap produktivitas karyawan bagian produksi Pada PT. L'essential?

c. Seberapa besar pengaruh lingkungan kerja dan Budaya organisasi terhadap produktivitas karyawan bagian produksi secara simultan Pada PT. L'essential?

\section{Hipotesis Penelitian}

Hipotesis adalah jawaban sementara terhadap masalah yang masih bersifat praduga karena harus dibukitkan kebenerannya. Menurut Sugiyono (2016:63). Hipotesis merupakan jawaban sementara terhadap rumusan masalah penelitian, dimana rumusan masalah penelitian telah dinyatakan dalam bentuk kalimat pertanyaan.

Berdasarkan rumusan masalah dan kerangka berpikir di atas, maka dirumuskan beberapa hipotesis dalam penelitian ini yaitu:

$\mathrm{H}_{\mathrm{o} 1}$ : Tidak terdapat pengaruh lingkungan kerja terhadap produktivitas karyawan pada PT. l'essential.

$\mathrm{H}_{\mathrm{a} 1}$ : Terdapat pengaruh lingkungan kerja terhadap produktivitas karyawan pada PT. l'essential.

$\mathrm{H}_{\mathrm{o} 2}$ : Tidak terdapat pengaruh budaya organisasi terhadap produktivitas pada PT. l'essential.
$\mathrm{H}_{\mathrm{a} 2}$ : Terdapat pengaruh budaya organisasi terhadap produktivitas pada PT. l'essential.

$\mathrm{H}_{\mathrm{o} 3}$ : Tidak terdapat pengaruh lingkungan kerja dan budaya organisasi terhadap produktivitas pada PT. l'essential.

$\mathrm{H}_{\mathrm{a} 3}$ : Terdapat pengaruh lingkungan kerja dan budaya organisasi terhadap produktivitas pada PT. l'essential

\section{TINJAUAN PUSTAKA}

\section{Lingkungan Kerja}

Lingkungan kerja dalam suatu perusahaan sangat penting untuk diperhatikan manajemen. Meskipun lingkungan kerja tidak melaksanakan proses produksi dalam suatu perusahaan, namun lingkungan kerja mempunyai pengaruh langsung terhadap para karyawan yang melaksanakan proses produksi tersebut. Lingkungan kerja adalah suasana dimana karyawan melakukan aktivitas setiap harinya.

Lingkungan kerja yang kondusif memberikan rasa aman dan memungkinkan karyawan untuk dapat bekerja optimal. Jika karyawan menyenangi lingkungan kerja dimana dia bekerja, maka karyawan tersebut akan betah ditempat kerjanya, melakukan aktivitasnya sehingga waktu kerja dipergunakan secara efektif. Sebaliknya lingkungan kerja yang tidak memadai akan dapat menurunkan kinerja karyawan.

Lingkungan kerja di dalam perusahaan/instansi sangat penting untuk diperhatikan oleh 
pimpinan karena lingkungan kerja yang baik mempunyai pengaruh terhadap efektivitas yang bekerja dalam perusahaan. Di dalam usaha untuk menbuat perencanaan lingkungan kerja maka perlu mengkaji dan menentukan aspekaspek pembentuk lingkungan kerja itu sendiri.

Menurut (Nitisemito dalam Nuraini 2013:97) lingkungan kerja adalah segala sesuatu yang ada disekitar karyawan dan dapat mempengaruhi dalam menjalankan tugas yang dikembangkan kepadanya misalnya dengan adanya air conditioner (AC), penerangan yang memadai dan sebagainya.

\section{Budaya Organisasi}

Budaya

hakekatnya

merupakan proses integrasi dari suatu perilaku manusia yang mencangkup pikiran, ucapan dan perbuatan dengan proses pembelajaran. Dalam kehidupannya manusia dipengaruhi oleh budaya dimana mereka berada. Hal yang sama akan terjadi di suatu organisasi atau perusahaan, bauran dari segala nilai, keyakinan dan perilaku dari setiap anggota organisasiakan membentuk budaya organisasi. Pengertian budaya organisasi menurut Robbins dalam wibowo (2013:37) adalah sistem nilai bersama dalam suatu organisasi yang menentukan tingkatan bagaimana para karyawan melakukan kegiatan untuk mencapai tujuan organisasi.

Dalam mempertahankan budaya organisasi di dalam organisasi, manajemen puncak
(Top Management) berperan sangat penting sehingga budaya organisasi bisa dipertahankan dan membuat karyawan memiliki pengalaman yang sama.

\section{Produktivitas}

Kata "Produktivitas" merupakan kata serapan dari bahasa Inggris yaitu Productivity atau gabungan dari 2 kata diantaranya "Product" dan "Aktivity" yang artinya adalah Kegiatan untuk menghasilkan sesuatu, baik itu berupa Barang maupun Jasa. Dalam Produksi, Produktivitas merupakan suatu pengukuran dimana produksi menggunakan sumber-sumber dayanya untuk mendapatkan hasil yang semaksimal mungkin. Dengan kata lain, Produktivitas merupakan rasio atau perbandingan antara Output yang dihasilkan dengan Input (sumber daya) yang digunakanya.

Produktivitas kerja menurut Hasibuan (2014:128) merupakan perbandingan antara keluaran dan masukan serta mengutarakan cara pemanfaatan baik terhadap sumber - sumber dalam memproduksi suatu barang atau jasa. Dari pemahaman di atas dapat dikatakan bahwa produktivitas menyentuh berbagai aspek dalam diri manusia seperti sikap, mental, etika dan keahlian sehingga dapat dijadikan sebagai pendorong dalam meningkatkan mutu untuk menjadi lebih baik setiap harinya.

\section{METODE PENELITIAN}

Metode penelitian yang digunakan adalah penelitian deskriptif/kuantitaf, yang artinya 
penelitian ini hanya sebatas pengungkapan suatu permasalahan yang ada dan mencoba menemukan solusi atau pemecahan masalah yang ada. Data yang diperoleh oleh kuesioner dengan jumlah responden sebanyak 50 orang. Dianalisis menggunakan bantuan Program microsoft Excel 2012 dan program SPSS 22 untuk melakukan Uji Validitas, Reabilitas, Normalitas, Parsial (t), Simultan (f) dan koefisien determinasi .

\section{HASIL DAN PEMBAHASAN}

Variabel penelitian Lingkungan Kerja dan Budaya Organisasi terhadap Poduktivitas Karyawan menunjukkan hasil uji $\mathrm{F}_{\text {hitung }}=44,597$ sedangkan $\mathrm{F}_{\text {tabel }}=$ $6,491\left(F_{\text {hitung }}>F_{\text {tabel }}\right)$ dengan taraf signifikansi $0,000<0,05$, maka dapat disimpulkan bahwa terdapat pengaruh yang signifikan positif antara Lingkungan kerja dan Budaya Organisasi secara simultan terhadap Produktivitas Karyawan.

Hasil Regresi Linear Sederhana $\mathrm{Y}=14,417+0,702 \mathrm{X}_{1}+0,494 \mathrm{X}_{2}+\mathrm{e}$. Artinya apabila tidak ada nilai Lingkungan Kerja dan Budaya Organisasi maka nilai Produktivitas Karyawan sebesar 0,702.

Koefisien korelasi peneliti dapat menarik kesimpulan dengan merujuk pada dasar pengambilan keputusan uji korelasi. Nilai korelasi antara Lingkungan Kerja dan Budaya Organisasi terhadap Produktivitas Karyawan sebesar 0,846 yang berarti korelasi bersifat sangat kuat

Koefisien Determinasi Model Summary pada kolom R Square hasil output perhitungan dengan menggunakan program SPSS versi 22 diketahui nilai koefisien determinasi $\left(\mathrm{R}^{2}\right)$ sebesar 0,655. Hal ini menunjukkan bahwa Lingkungan Kerja dan Budaya Organisasi mempengaruhi Produktivitas Karyawan sebesar $65,5 \%$ sedangkan sisanya $34,5 \%$ dipengaruhi oleh faktor-faktor lain diluar model penelitian ini.

\section{PENUTUP}

\section{Kesimpulan}

Berdasarkan dari hasil penelitian dan pembahasan yang telah di uraikan peneliti, maka dapat disimpulkan bahwa:

Lingkungan kerja yang ada di PT. L'ssential, bisa kita lihat responden yang menjawab baik (B) dengan pernyataan " Ruangan tempat anda bekerja dengan udara yang panas dapat membuat anda lebih terampil dalam mengerjakan pekerjaan anda sehingga pekerjaan dapat diselesaikan tepat waktu" menjadi pernyataan yang paling berpengaruh bagi responden dan rata-rata keseluruhan variabel Lingkungan Kerja adalah 3,66 yang berarti baik (B).

Budaya Organisasi yang ada di PT. L'essentisl, bisa kita lihat responden yang menjawab kategori baik (B) dengan pernyataan " Saya merasa kurangnya kerjasama yang terjadi antara tutor yang satu dengan yang lainnya" menjadi pernyataan yang paling berpengaruh bagi responden dan rata-rata keseluruhan variabel Budaya Organisasi adalah 4,34 yang berarti baik (B).

Produktivitas Karyawan yang ada di PT. L'essential, bisa kita lihat responden yang 
menjawab kategori baik (B) dengan pernyataan "Saya bekerja sesuai dengan program kerja" menjadi pernyataan yang paling berpengaruh bagi responden dan rata-rata keseluruhan variabel Produktivitas Karyawa adalah 4,02 yang berarti baik (B).

Terdapat pengaruh positif dan signifikan antara Lingkungan Kerja dan Budaya Organisasi secara simultan terhadap Produktivitas Karyawan yang ditunjukan dengan $\mathrm{Y}=18,619+$ $0,702 \mathrm{X} 1+0,494 \mathrm{X} 2+\mathrm{e}$ artinya apabila Lingkungan Kerja meningkat satu kesatuan Produktivitas Karyawan akan mengalami kenaikan sebesar 0,496. Dan apabila Budaya Organisasi meningkat satu kesatuan Produktivitas Karyawan akan mengalami kenaikan sebesar 0,361 . koefisien determinasi ( $R$ square) sebesar 0,655 maka dapat disimpulkan bahwa variabel organisasi Lingkungan Kerja(X1), Budaya Organisasi (X2), secara bersama-sama berpengaruh terhadap variabel Produktivitas Karyawan (Y) sebesar 65,5\% sedangkan sisanya $34,5 \%$ dipengaruhi oleh faktor lain. Hasil uji $F$ menunjukkan Fhitung $=44,597$ sedangkan Ftabel $=3,20$ (Fhitung > Ftabel) dengan taraf signifikansi $0,000<0,05$, maka dapat disimpulkan bahwa terdapat pengaruh positif dan signifikan antara Lingkungan Kerja dan Budaya Organisasi secara simultan terhadap Produktivitas Karyawan pada atau dengan kata lain $\mathrm{H} 0$ ditolak dan $\mathrm{H} 1$ diterima.

\section{Saran}

Berdasarkan

hasil pembahasan dan kesimpulan mengenai Lingkungan Kerja, dan Budaya Organisasi TerhadapProduktivitas, maka saran yang dapat peneliti ajukan sebagai berikut:

Dari hasil penelitian variabel Lingkungan Kerja, indikator yang paling lemah adalah keamanan dengan hanya memperoleh skor 131 dengan meningkatakan kenyaman dan keselamatan kerja bagi para karyawan.

Kemudian variabel Budaya Organisasi, indikator yang paling lemah adalah indikator orientasi hasil dengan hanya memperoleh skor 148 yang berarti perusahaan memberikan apresiasi kepada para karyawan yang menyelesaikan targetnya.

Dan Produktivitas karyawan, indikator yang paling lemah adalah indikator efisien dengan hanya memperoleh skor 124 yang berarti perusaahan memberikan waktu pekerjaan sesuai dengan kapasitas karyawan.

Menurut peneliti, perlu di lakukan penelitian lain dengan variabel X1 selain Lingkungan Kerja (Max saleleng, Agus supandi soegoto 2015), Pengaruh lingkungan kerja, motivasi, pelatihan dan kompensasi terhadap kinerja karyawan.

.Menurut peneliti, perlu di lakukan penelitian lain dengan variabel X2 selain Budaya Organisasi (Pilatus deikme 2013), Motivasi kerja dan budaya organisai pengaruhnya terhadap kinerja pegawai. 
Mengingat Pengaruh Lingkungan Kerja Dan Budaya Orgasnisasi Terhadap Produktivitas Karyawan tergolong tinggi $(65,5 \%)$ maka PT. L'essential perlu untuk dapat mengelola Lingkungan Kerja dan Budaya Organisasi pada Produktivitas Karyawan.

\section{DAFTAR PUSTAKA}

Algifari (2015) Analisis Regresi, Teori, Kasus dan Solusi. Edisi pertama. BPFE Universitas Gajah Mada, Yogyakarta

Arikunto, Suharsimi. (2015). Penelitian Tindakan Kelas edisi. Jakarta: Bumi Aksara.

Deikme Pilatus (2013) Universitas Sam Ratulangi Jurnal EMBA vol.1

Ghozali Imam. (2016) Aplikasi Analisis Multivariete Dengan Program IBM SPSS 23 (Edisi 8). Cetakan ke VIII. Semarang : Badan Penerbit Universitas Diponegoro.

Hasibuan S.P (2016) Manajemen Sumber Daya Manusia. Edisi Revisi. Jakarta: Penerbit PT Bumi Aksara.

Mangkunegara Prabu (2013) Manajemen Sumber Daya ManusiaPerusahaan, Remaja Rosdakarya, Bandung.

Muhammad Rahayu , dkk (2016) Universitas Samratulangi Manado Jurnal EMBA vol. 4

Nuraini (2013) Manajemen Sumber Daya Manusia, Yayasan Aini Syam: Pekanbaru.
Rivai (2014) Manajemen Sumber Daya Manusia Untuk Perusahaan.Jakarta: PT Raja Grafindo Persada

Robbins P, dkk (2013). Organizational Behavior Edition 15 New Jersey: Pearson Education.

Sahlan Ikhsan , dkk (2015) Universitas Sam Ratulangi Manado Jurnal EMBA vol.3

Saleleng Max, dkk (2015) Universitas Sam Ratulangi Manado Jurnal EMBA vol.3

Sedarmayanti (2013) Manajemen Sumber Daya Manusia, Bandung: Refika Aditama.

Santoso Singgih (2013) Panduan Lengkap Menguasai Statistik Dengan SPSS.Jakarta: PT. Elex media Komputindo

Sinambela, dkk (2016) Manajemen Sumber Daya Manusia. Jakarta: PT Bumi Aksara

Subekhi, dkk (2013) Pengantar Manajemen Sumber Daya Manusia. Surabaya: Prestasi Pustaka.

Sugiyono (2016) Penelitian Kuantitatif, Kualitatif dan R\&D. Bandung: PT Alfabet.

Supangat Andi (2013) Statistika Dalam Kajian Deskriptif, Inferensi dan Parametrik. Jakarta: Kencana Prenada

Sutrisno Edi (2016) Manajemen Sumber Daya Manusia. Jakarta : Prenadamedia Group.

Wuwungan Yulia, dkk (2017) Universitas Sam Ratulangi Jurnal EMBA vol. 5. 